\title{
EFFECT OF SOME DISPERSING AUXILIARIES ON NANOSILICA DISPERSION INTO PASSIVE CHROME TRIVALENT SOLUTION
}

\author{
Truong Thi Nam ${ }^{1, *}$, Hoang Thi Huong Thuy ${ }^{3,4}$, Dao Phi Hung1, \\ Le Ba Thang ${ }^{1}$, Nguyen Thi Cam $\mathrm{Ha}^{2}$ \\ ${ }^{1}$ Institue for Tropical Technology, VAST, 18 Hoang Quoc Viet, Cau Giay, Ha Noi \\ ${ }^{2}$ Faculty of Chemistry, VNU University of Science, 19 Le Thanh Tong, Ha Noi \\ ${ }^{3}$ Faculty of Chemistry, Ha Noi University of Education, 136 Xuan Thuy, Cau Giay, Ha Noi \\ ${ }^{4}$ Hong Duc University, 565 Quang Trung, Thanh Hoa city, Thanh Hoa \\ "Email: namtruong1208@gmail.com
}

Receited: $28^{\text {th }}$ August 2015; Accepted for publication: 29 March 2016

\begin{abstract}
Effect of dispersing auxiliaries, namely polyvinylpyrrolidone (PVP), Lauryl dodecyl sulfate sodium (SDS), nonionic surfactant op-10 (Op-10), C12-14 alcohol ethoxylate AE7 (AE7) and polyethylenimine (epomin) on the nanosilica dispersion into passive $\mathrm{Cr}$ (III) solution, $\mathrm{pH}=1.5$, were investigated by FT-IR, zeta potential, particle-size distribution and natural salt spray testing. The obtained results indicated that passive $\mathrm{Cr}$ (III)-nanosilica solution after 7-day fabrication was uniform, having no agglomeration if using SDS, PVP and AE7 agent. AE7 saw the best dispersion aid ability for dispersing nanosilica into passive $\mathrm{Cr}$ (III) solution in those dispersing auxiliaries studied. Conversion coating fabricated from passive $\mathrm{Cr}$ (III)-nanosilicaAE7 solution had a highest level of anticorrosion durability. White rust appeared on X-Cut position of sample fabricated from former solution after 9-day natural salt spray testing, which was the longest in all of samples. However, average particle size of nanosilica in passive $\mathrm{Cr}$ (III)nanosilica-AE7 solution was approximately $60 \mathrm{~nm}$, which was quintuple initial average nanosilica size. Hence, AE7 could help nanosilica dispersion into passive $\mathrm{Cr}$ (III) solution but effect of AE7 was not strong enough to disperse nanosilica well into solution as well as maintaining the stability for new system.
\end{abstract}

Keywords: Chrome trivalent, nanosilica, dispersing auxiliaries, conversion coating, zinc plating.

\section{INTRODUCTION}

Zinc plating is widely used to against corrosion for steel due to the low cost and simple technology [1 - 4]. However, zinc coating's rate of corrosion might be very large in a humid environment since zinc is a chemically high reactive metal. Therefore, a post-treatment is necessary to increase the lifetime of zinc coatings. In industrial practice, one of the most popular methods was to use passive $\mathrm{Cr}(\mathrm{VI})$ solution to create a thin conversion coating on the surface of zinc plating with self-healing ability. However, the compound $\mathrm{Cr}(\mathrm{VI})$ has been convinced as a 
hazardous substance that may cause cancer. The use of compounds $\operatorname{Cr}(\mathrm{VI})$ is increasingly forbidden by European countries and others over the world [5, 6]. Hence, many other treatment methods have been presented with requirements to replace $\mathrm{Cr}(\mathrm{VI})$ based conversion coatings with safer treatments [6], in which $\mathrm{Cr}(\mathrm{III})$ conversion coating is introduced and become popular in industrial practice.

In Vietnam, some research organizations such as Hanoi University of Science and Technology, the VNU University of Science and Institute for Tropical Technology etc. have been studying and fabricating successfully passive $\mathrm{Cr}$ (III) solutions. Nevertheless, the combination of nanosilica with trivalent chromium conversion coating is a novel research direction, where there are very few reports published in the world, with purpose to fabricate a conversion coating with high anticorrosion durability and self-healing ability. However, it is hard to disperse nanosilica in low $\mathrm{pH}$ solution [7]. Nanosilica powders easily agglomerate in low $\mathrm{pH}$ solution. Hence, the requirement of passive $\mathrm{Cr}$ (III) nanosilica solution is stability as reduce the agglomeration of nanosilica. In this paper, effect of some dispersion aids on the nanosilica powder dispersion in passive $\mathrm{Cr}$ (III) solution has been investigate by zeta potential, particle-size distribution, FT-IR with a desire to determine suitable dispersion aid for dispersing nanosilica into $\mathrm{Cr}$ (III) solution.

\section{MATERIALS AND METHODS}

\subsection{Materials}

The chemical materials are used which include: $\mathrm{NaOH}, \mathrm{HNO}_{3}$ (both used pure grade (China)), iridescent passive $\mathrm{Cr}(\mathrm{III})$ complex solution (containing: $\mathrm{Cr}^{3+}$ in type $\mathrm{Cr}_{2}\left(\mathrm{SO}_{4}\right)_{3} \cdot 6 \mathrm{H}_{2} \mathrm{O}$ at $5 \mathrm{~g} / \mathrm{L}$, complexion agent at $16 \mathrm{~g} / \mathrm{L}$ and $\mathrm{pH}$ at 1.5 and was fabricated at Institute for Tropical Technology). Zinc electroplating was fabricated according to the ENTHONE process [5]. The components of zinc plating solution are $\mathrm{ZnCl}_{2}(60 \mathrm{~g} / \mathrm{L}) ; \mathrm{NH}_{4} \mathrm{Cl}(250 \mathrm{~g} / \mathrm{L})$; additive AZA (30 $\mathrm{ml} / \mathrm{L}$ ) and AZB (1.5 ml/L). Nanosilica Aerosil (Belgium) has a specific surface area of $200 \mathrm{~m}^{2} / \mathrm{g}$ and average diameter of $12 \mathrm{~nm}$. Some of dispersing auxiliaries: polyvinylpyrrolidone (PVP) (France), Lauryl dodecyl sulfate sodium (SDS), nonionic surfactant op-10 (Op-10), C12-14 alcohol ethoxylate AE7 (AE7) and polyethylenimine (epomin) (China).

\subsection{Preparation of passive trivalent chromium with nanosilica solution.}

Preparation of passive trivalent chromium solution containing nanosilica:

+ A: $1 \mathrm{~g}$ of nanosilica was dispersed in $100 \mathrm{~mL}$ distilled water by ultrasonic machine TPC15 (Swiss) with frequency of $20 \mathrm{kHz}$ and power of $30 \mathrm{~W}$ in 10 minutes.

+ B: $100 \mathrm{~mL} \mathrm{Cr}(\mathrm{III})$ solution was diluted by $700 \mathrm{~mL}$ distilled water and then $0.1 \mathrm{~g}$ surfactant was added which was followed by vibrating with ultrasound machine TPC-15 for 5 minutes.

Finally, A and B were mixed and deionized water was added to the $1 \mathrm{~L}$ of solution. After that, the solution was vibrated again in $10 \mathrm{~min}$. $\mathrm{pH}$ of solution was adjusted to $1.5-1.8$ by $10 \%$ of $\mathrm{NaOH}$ and $10 \%$ of $\mathrm{HNO}_{3}$ solution.

Table 1 illustrated notation of passive $\mathrm{Cr}$ (III) solution and nanosilica with different dispersing auxiliaries. 
All of passive $\mathrm{Cr}$ (III)-nanosilica solution with various surfactants were fabricated and then stabilised in $24 \mathrm{~h}$, which was followed by ultrasound treatment in $10 \mathrm{~min}$ before further analysis.

Table 1. The notation of passive $\mathrm{Cr}$ (III) solution and nanosilica with various agents.

\begin{tabular}{|l|c|}
\hline \multicolumn{1}{|c|}{ Passive solution } & \multicolumn{1}{c|}{ Notation } \\
\hline Passive Cr(III)-nanosilica solution, dispersing agent SDS & $\mathrm{Cr}(\mathrm{III})-\mathrm{SiO}_{2}$-SDS \\
\hline Passive Cr(III)-nanosilica solution, dispersing agent PVP & $\mathrm{Cr}(\mathrm{III})-\mathrm{SiO}_{2}$-PVP \\
\hline Passive Cr(III)-nanosilica solution, dispersing agent $\mathrm{AE7}$ & $\mathrm{Cr}(\mathrm{III})-\mathrm{SiO}_{2}$-AE7 \\
\hline Passive Cr(III)-nanosilica solution, dispersing agent op-10 & $\mathrm{Cr}(\mathrm{III})-\mathrm{SiO}_{2}$-Op10 \\
\hline Passive Cr(III)-nanosilica solution, dispersing agent epomin & $\mathrm{Cr}(\mathrm{III})-\mathrm{SiO}_{2}$-Ep \\
\hline
\end{tabular}

\subsection{Zinc electroplating preparation}

Steel low carbon plates $(100 \times 50 \times 1.2 \mathrm{~mm})$ were degreased by immersion in UDYPREP$110 \mathrm{EC}$ (Enthone) with $60 \mathrm{~g} / \mathrm{L}$ of concentration at $50-60{ }^{\circ} \mathrm{C}$ of temperature for $5-10 \mathrm{~min}$. After that the samples were immersed in solution containing $\mathrm{HCl}(10 \%)$, urotropin $(3.5 \mathrm{~g} / \mathrm{L})$ at ambient temperature for 2 - $5 \mathrm{~min}$.

The steels were industrially electrogalvanized in plating bath with solution of Enthone Company. The conditions were followed: cathodic current density of $2 \mathrm{~A} / \mathrm{dm}^{2}$; the zinc anode with a purity of $99.995 \%$; rate of square anode/cathode of $2 / 1$ and at ambient temperature for 30 min with the swinging cathode operation. Subsequently, the samples were rinsed by deionized water. Zinc coating had thickness of $12-13 \mu \mathrm{m}$.

Immediately after the electrogalvanizing step, the sample surface was activated in a $0.5 \%$ $\mathrm{HNO}_{3}$ solution $(\mathrm{pH} 1)$ for $3-5 \mathrm{~s}$. Subsequently, the surface was passivated by the following treatments green-colored $\mathrm{Cr}^{3+}$ (with and without nanosilica)-based conversion treatment. The parameters used were $\mathrm{pH} 1.5$, in $60 \mathrm{~s}$ in industrial immersion bath with mechanical stirring. Finally, the samples were rinsed in deionized water and dried in an oven at $80^{\circ} \mathrm{C}$ for $30 \mathrm{~min}$. All samples were stored in desiccators at ambient temperature in $48 \mathrm{~h}$ for stabilized samples.

\subsection{Analysis}

+ Stability and flocculation of nanosilica in solution was assessed by general appearance immediately and after 7-days fabrication.

+ Functional group of passive solution compounds was determined by means of an FT-IR spectrophotometer (Perkin Elmer GX) with $4000-400 \mathrm{~cm}^{-1}$ of range wave number and resolution at $4 \mathrm{~cm}^{-1}$.

+ The particle-size distribution of nanosilica in the passive $\mathrm{Cr}$ (III) solution measured using laser scattering particle-size distribution analyzer (LA 950V2, Horiba) produced a wide range of $0.01 \mu \mathrm{m}$ to $3000 \mu \mathrm{m}$ and resolution $<0.01 \mu \mathrm{m}$.

+ Zeta potential was determined by using the Doppler velocity technique on ZetasizerNano ZS equipment (Malvern - UK) that had a measuring range of $-200 \div+200 \mathrm{mV}$.

+ The neutral salt spray was tested on X-cut positions on sample surface fabricated form various passive $\mathrm{Cr}$ (III)-nanosilica solutions according to standard JIS 8502:1999 by means Q- 
FOG CCT 600 (USA) at Institute for Tropical Technology, VAST.

\section{RESULTS AND DISCUSSION}

\subsection{General appearance assessment}

Although general appearance assessment is simple technique with non-equipment, obtained results is important in orienting further studies and thus saving time and money for research. Initially, all of passive solution with different agents were assessed appearance immediately fabricated and after 7 days with purpose to selecting suitable agent with nanosilica dispersion into low $\mathrm{pH}$ solution. The results indicated that almost solutions were uniform and stabilized after 7-day fabrication except $\mathrm{Cr}(\mathrm{III})-\mathrm{SiO}_{2}-\mathrm{Op} 10$ and $\mathrm{Cr}(\mathrm{III})-\mathrm{SiO}_{2}-\mathrm{Ep}$ which had nanosilica agglomeration after 7-day fabrication. Therefore, passive $\mathrm{Cr}(\mathrm{III})-\mathrm{SiO}_{2}$ solution containing dispering agents, namely SDS, PVP and AE7 have been selected for further studies.

\subsection{Zeta potential and particle-size distribution}

\subsubsection{Zeta potential}

The stability of solution is an important criterion for dispersed nanomaterials into solution in general and dispersed nanosilica into solution in particular, especially in cases dispersing nanomaterial in unstable conditions, such as dispersing nanosilica into low $\mathrm{pH}$ solution, and thus testing stability of solution to find out suitable fabricating condition and stability enhancer is indispensable. Zeta potential can be used to determine the stability of dispersed nano solution. Zeta potential values of passive $\mathrm{Cr}(\mathrm{III})-\mathrm{SiO}_{2}$ solutions were presented on Table 2.

Table 2. Zeta potential of passive dispersed nanosilica solutions.

\begin{tabular}{|c|c|c|c|}
\hline Passive solution & $\mathrm{Cr}(\mathrm{III})-\mathrm{SiO}_{2}$-SDS & $\mathrm{Cr}(\mathrm{III})-\mathrm{SiO}_{2}-\mathrm{PVP}$ & $\mathrm{Cr}(\mathrm{III})-\mathrm{SiO}_{2}-\mathrm{AE} 7$ \\
\hline Zeta potential $(\mathrm{mV})$ & $-4,5$ & $-4,9$ & $-6,1$ \\
\hline
\end{tabular}

As can be seen from Table 2, algebraic values of Zeta potentials were not high. It means that colloid solutions were poor stability and unreliability due to characteristic nanosilica, which is easily agglomerated in low pH solution. According to previous studies, Zeta potentials' algebraic values of nanosilica colloid solution at low $\mathrm{pH}$ was usually small, for example, Zeta potential value was approximately zero at $\mathrm{pH}=1$. At $\mathrm{pH}=3$, nanosilica in colloid solution absence of dispersing auxiliaries started flocculation [7]. The obtained results showed that, dispersing agents enhanced Zeta potential leading to passive solutions containing nanosilica was stabilized in a higher level, after 7-day fabricated solutions were still uniform and of nonagglomeration.

As from Table 2, $\mathrm{Cr}$ (III)-SiO $\mathrm{S}_{2}$-AE7 solution experienced the highest zeta potential algebraic value than $\mathrm{Cr}(\mathrm{III})-\mathrm{SiO}_{2}-\mathrm{PVP}$ and $\mathrm{Cr}(\mathrm{III})-\mathrm{SiO}_{2}$-SDS solution. Hence, the $\mathrm{Cr}(\mathrm{III})-\mathrm{SiO}_{2}-\mathrm{AE} 7$ solution was, to some extent, the most stable in comparison with $\mathrm{Cr}(\mathrm{III})-\mathrm{SiO}_{2}-\mathrm{PVP}$ and $\mathrm{Cr}(\mathrm{III})-$ $\mathrm{SiO}_{2}$-SDS solution. 


\subsubsection{Particle-size distribution}

Particle size can affect to not only the stability of solution but also conversion coating containing nanosilica. For example, nanosilica affects insignificantly to microstructure and morphology of conversion coating surface if the size of nanosilica is small enough [9]. However, nanosilica particle-size depends not only on initial size of nanosilica but also on dispersing condition, and surface of nanosilica status. Therefore, using the dispersing auxiliaries or modifying surface of nanosilica can lead to reducing diameter of nanosilica as well as reducing of agglomeration. The obtained results of particle-size distributions are displayed on Figure 1.

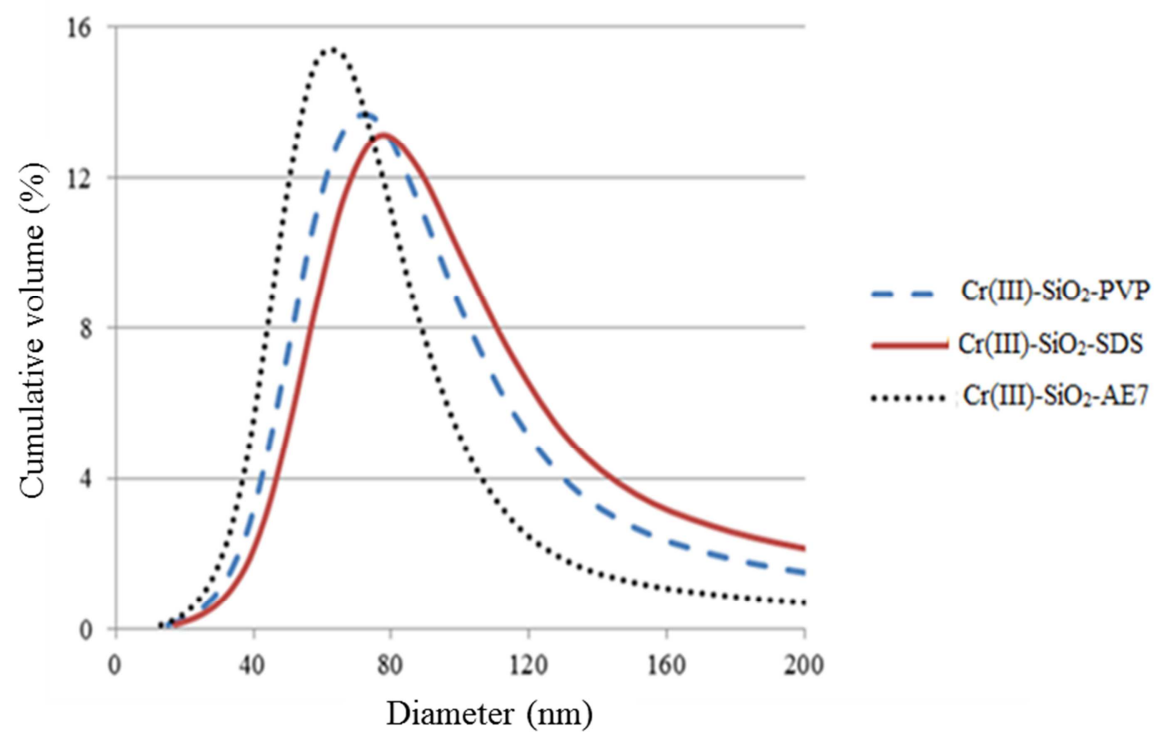

Figure 1. Particle-size distribution of nanosilica in passive solution containing dispersing auxiliaries.

As can be seen from Figure 1, the average particle size of nanosilica in passive solution using different dispersing agents could be arranged follow: AE7 $(59.51 \mathrm{~nm})<$ PVP $(70.9 \mathrm{~nm})$ $<$ SDS $(79.07 \mathrm{~nm})$. Particle size of nanosilica in passive solution was much higher than that of initial nanosilica (approximately $12 \mathrm{~nm}$ of average size). It can be explained that, nanosilica easily agglomerated at low $\mathrm{pH}$, nanosilica started agglomeration at $\mathrm{pH}=3$ [7]. Because proton $\mathrm{H}^{+}$from environment easily attached to oxygen of nanosilica to create $\mathrm{Si}-\mathrm{OH}$ and then the hydrogen bond established $[4,8]$. Thus, nanosilica agglomerated to create a huge particle when nanosilica was dispersed into solution at $\mathrm{pH}=1.5$. With presence of dispersing auxiliaries, dispersing agents could covered around nanosilica, preventing interraction of nanosilica and proton from environment leading to slow transition from $\mathrm{SiO}$ to $\mathrm{Si}-\mathrm{OH}$ as well as reducing process of flocculation of silica in an acid environment. Hence, nanosilicas were, up to a point, better dispersed into passive solution at $\mathrm{pH}=1.5$ with dispersing agent in comparison with solution absence dispersing auxiliaries [7]. However, average particle size of nanosilica in passive solution using dispersing agents was lager in comparison with initialy diameter of nanosilica and thus it was not exaggerating to say that effect of dispersing auxiliaries in this study were, more or less, not enough to dispersing nanosilica as well as stabilizing new system.

From obtained results of Zeta potential and particle-size distribution, dispersing auxiliaries of dispersion aids of nanosilica into passive Cr(III) solution can be arranged as follows: SDS< 
PVP < AE7. Thus, passive Cr(III)-nanosilica solution using AE7 agent was predicted to create conversion coating with the highest protection ability.

\subsection{IR analysis}

IR spectroscopy was used to determine functional groups and chemical links which indicated relationship between nanosilica and compounds in passive $\mathrm{Cr}$ (III)-nanosilica solution with dispersing auxiliaries. IR spectra of passive Cr(III)-nanosilica solution with different agents were illustrated on Figure 2.

As can be seen from Figure 2a, absorbance at $3200-3700 \mathrm{~cm}^{-1}$ with strong intensity is corresponding characteristic $-\mathrm{OH}$ of silanol $(\mathrm{SiOH})$ and water linked with nanosilica surface by hydrogen bond. Besides, absorbance of $\mathrm{OH}$ group also shown at $3440 \mathrm{~cm}^{-1}$ and $1645 \mathrm{~cm}^{-1}$, is corresponding of characteristic -OH group in water [8].

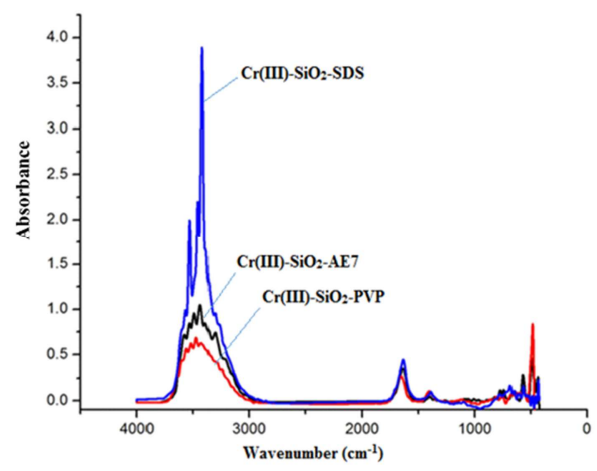

(a)

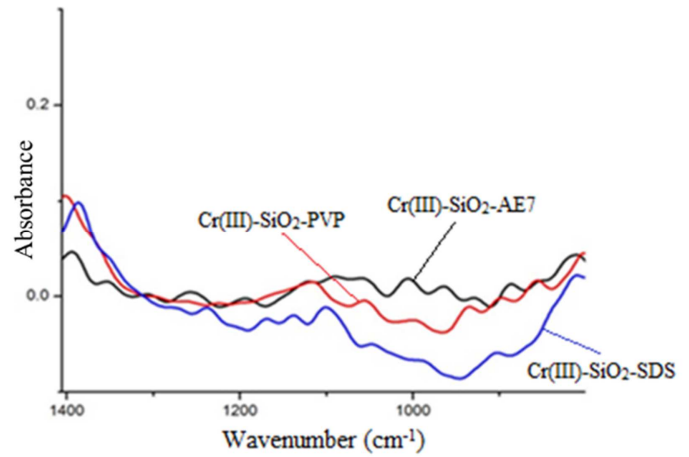

(b)

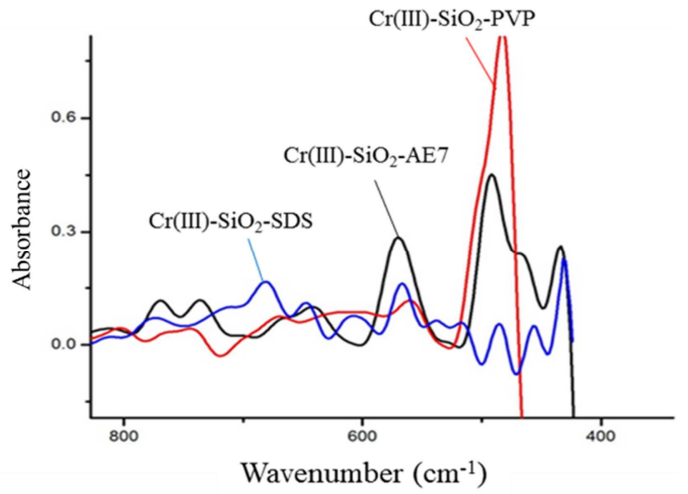

(c)

Figure 2. IR spectrum of passive $\mathrm{Cr}(\mathrm{III})-\mathrm{SiO}_{2}$ solution with different dispersing agents produced wavenumber range of $4000-400 \mathrm{~cm}^{-1}$ (a); $1400-800 \mathrm{~cm}^{-1}$ (b) and $800-400 \mathrm{~cm}^{-1}$ (c).

Figure $2 \mathrm{~b}$ shows that absorbance peak of $\mathrm{SiO}_{2}$ in passive solution with different dispersing agents were various wavenumber at $1078 \mathrm{~cm}^{-1}, 1094 \mathrm{~cm}^{-1}, 1099 \mathrm{~cm}^{-1}, 1103 \mathrm{~cm}^{-1}$. Absorbance at $1093 \mathrm{~cm}^{-1}$ và $770 \mathrm{~cm}^{-1}$ were corresponded to fluctuating asymmetry of -Si-O-Si and fluctuating symmetry of Si-OH, respectively. Moerover, absorbance at $953 \mathrm{~cm}^{-1}$, corresponding to characteristic $\mathrm{Cr}(\mathrm{VI})$ was not appeared while absorbance at range $610-600 \mathrm{~cm}^{-1}$ was corresponded with $\mathrm{Cr}^{3+}$ [3]. This results were compatible with photometry results of passive Cr(III)-nanosilica. 


\subsection{Natural salt spray testing}

Natural salt spray testing is one of accelerated test methods, which are the most popular and widest methods, using to evaluation anticorrosion durability of coating on metal. In this work, natural salt spray testing was used with a desire to compare the anticorrosion of samples which were fabricated from passive $\mathrm{Cr}(\mathrm{III})$-nanosilica solution using various dispersing agents.

Time of white rust appearance on X-cut positions of samples were determined in natural salt spray testing. Time of white rust appearance on X-cut positions of samples which were fabricated from various passive solution were presented on Table 3.

Table 3. Time of white rust appearance on on X-cut positions of samples which were fabricated from passive $\mathrm{Cr}(\mathrm{III})-\mathrm{SiO}_{2}$ solution using different dispersing agents.

\begin{tabular}{|l|c|}
\hline \multicolumn{1}{|c|}{ Sample fabricated from } & $\begin{array}{c}\text { Time of white rust } \\
\text { appearance (day) }\end{array}$ \\
\hline Passive $\mathrm{Cr}(\mathrm{III})$ solution & 1 \\
\hline Passive $\mathrm{Cr}(\mathrm{III})-\mathrm{SiO}_{2}$-SDS solution & 8 \\
\hline Passive $\mathrm{Cr}$ (III)- $\mathrm{SiO}_{2}$-PVP solution & 8 \\
\hline Passive $\mathrm{Cr}(\mathrm{III})-\mathrm{SiO}_{2}$-AE7 solution & $\mathbf{9}$ \\
\hline Passive $\mathrm{Cr}(\mathrm{III})-\mathrm{SiO}_{2}$-Op10 solution & 6 \\
\hline Passive $\mathrm{Cr}(\mathrm{III})-\mathrm{SiO}_{2}$-Ep solution & 6 \\
\hline
\end{tabular}

Nanosilica can affect insignificantly to microstructure and morphology of conversion coating surface if the its size is small enough [9]. However, anticorrosion of conversion coating based on $\mathrm{Cr}(\mathrm{III})$-nanosilica on zinc plating significantly improved. White rust appeared earlies, 1 day, on X-cut position on sample based on $\mathrm{Cr}$ (III) conversion coaitng while X-cut positions on other sample only appeared white rust after 6 day or later. It can be explained that with presence of nanosilica, the anticorrosion durability of conversion coating substantially enhanced due to self-healing of nanosilica. These results were compatible with previous results. Passive $\mathrm{Cr}$ (III)nanosilica solution using AE7 agent, up to a point, fabricated conversion coating which was at highest level of anticorrosion ability.

\section{CONCLUSION}

Influence of various dispersing auxiliaries on the nanosilica dispersion into passive $\mathrm{Cr}$ (III) solution were investigated. AE7 shown the best dispersing aid ability in the comparion with dispersing auxiliaries stuty. However, average particle size of nanosilica in $\mathrm{Cr}$ (III)-nanosilicaAE7 was approximately $60 \mathrm{~nm}$, which was quintuple initial average nanosilica. Hence, effect of AE7 was not strong enough either to enhance nanosilica dispersion into passive $\mathrm{Cr}$ (III) solution or to creat a stbility for system. IR spectrum shown that passive $\mathrm{Cr}$ (III) solution did not contain $\mathrm{Cr}(\mathrm{VI})$. Characteristic absorbance of functional group indicated interraction between nanosilica and compounds in passive solution with dispering agents. 


\section{REFERENCES}

1. George F. Hays (Director General of World Corrosion Organization) - Corrosion Costs and the Future (2012). (http://corrosion.org/).

2. Porter F.C. - Corrosion resistance of zinc and zinc alloys - Marcel Dekker, Inc. (1994).

3. Nguyen Thi Thanh Huong, Le Ba Thang, Truong Thi Nam, Nguyen Van Chien, Nguyen Van Khuong, Le Duc Bao - Study on morphology, structure of $\mathrm{Cr}^{3+}$ conversion coating on electrodeposited zinc coating, Journal of Science and Technology 53 (2015) 221- 230.

4. Di Sarli A. R., Culcasi J. D., Tomachuk C. R., Elsner C.I., Ferreira-Jr J. M., Costa I. - A conversion layer based on trivalent chromium and cobalt for the corrosion protection of electrogalvanized steel, Surface \& Coatings Technology 258 (2014) 426-436.

5. Preikschat P., Jansen R. and Hulser P. - Chromate-free conversion layer and process for producing the same-US Patent 6287704. (2001).

6. Grasso L., Fantoli A. S., Ienco M. G. et al. - Corrosion resistance of $\mathrm{Cr}(\mathrm{III})$ based conversion layer on zinc coatings in comparison with a traditional $\mathrm{Cr}(\mathrm{VI})$ based passivation treatment, Corrosion 6 (2006) 31-39.

7. Mohamed Bizi - Stability and flocculation of nanosilica by conventional organic polymer, Natural Science 4 (2012) 372-385.

8. Peng L., Qisui W., Xi L., Chaocan Z. - Investigation of the states of water and OH groups on the surface of silica, Colloids and Surfaces A: Physicochemical and Engineering Aspects 334 (2009) 112-115.

9. Truong Thi Nam, Hoang Thi Huong Thuy, Le Ba Thang, Dao Phi Hung, Nguyen Thi Cam Ha, Hoang Van Hung - The effect of nanosilica to the trivalent chromium conversion coatings on zinc electroplating, Journal of Science and Technology 53 (4A) (2015) 87-95.

\section{TÓM TẮT}

\section{ẢNH HƯỞNG CỦA MỘT SỐ CHÂTT TRỢ PHÂN TÁN ĐẾN SỰ PHÂN TÁN NANOSILICA TRONG DUNG DỊCH THỤ ĐỘNG CROM (III)}

Trương Thị Nam ${ }^{1, ~ *}$, Hoàng Thị Hương Thủy ${ }^{3,4}$, Đào Phi Hùng ${ }^{1}$, Lê Bá Thắng ${ }^{1}$, Nguyễn Thị Cẩm Hà ${ }^{2}$

${ }^{l}$ Viện Kỹ thuật nhiệt đới, Viện Hàn lâm KHCNVN, 18, Hoàng Quốc Việt, Hà Nội

${ }^{2}$ Khoa Hóa, Truờng Đại học Khoa học Tụ nhiên, ĐHQGHN, 19, Lê Thánh Tông, Hà Nội

${ }^{3}$ Khoa Hóa, Truòng Đại học Su phạm Hà Nội, 136, Xuân Thủy, Hà Nội

${ }^{4}$ Truờng Đại học Hồng Đức, 565, Quang Trung, thành phố Thanh Hoá

*Email: namtruong1208@gmail.com

Ảnh hưởng của một số loại chất hỗ trợ phân tán, như polyvinylpyrrolidone (PVP), natri lauryl dodecyl sulfate (SDS), chất hoạt động bề mặt không ion op-10 (Op-10), C12-14 alcohol ethoxylate $\mathrm{AE7}$ ( $\mathrm{AE7}$ ) and polyethylenimine (epomin) đển quá trình phân tán nanosilica vào 
trong dung dịch thụ động $\mathrm{Cr}(\mathrm{III})$ có $\mathrm{pH}=1,5$ đã được nghiên cứu bằng phổ hồng ngoại, thế zeta, phân bố kích thước hạt và thử nghiệm mù muối. Kết quả cho thấy dung dịch thụ động $\mathrm{Cr}(\mathrm{III})-$ nanosilica đồng nhất và không có kết tụ các hạt silica sau khi chế tạo và sau 7 ngày khi sử dụng thêm tác nhân SDS, PVP and AE7. Tác nhân AE7 cho thấy khả năng trợ phân tán tốt nhất cho nanosilica vào trong dung dịch thụ động $\mathrm{Cr}(\mathrm{III})$ so với các tác nhân khác được nghiên cứu. Màng thụ động được chế tạo từ dung dịch thụ động $\mathrm{Cr}$ (III)-nanosilica-AE7 có độ bền chống ăn mòn tốt nhất. Vết gỉ trắng trên vết rạch của mẫu được chế tạo từ dung dịch trên xuất hiện sau 9 ngày phun muối, lâu nhất so với các mẫu khác. Tuy nhiên, kích thước trung bình của hạt nanosilica trong dung dịch $\mathrm{Cr}(\mathrm{III})$-nanosilica-AE7 khoảng $60 \mathrm{~nm}$ lớn hơn gấp 5 lần so với kích thước hạt nanosilica ban đầu $(12 \mathrm{~nm})$. Do đó, tác nhân $\mathrm{AE7}$ có thể giúp nanosilica phân tán vào trong dung dịch thụ động $\mathrm{Cr}(\mathrm{III})$ tốt nhất trong các tác nhân nghiên cứu, nhưng ảnh hưởng của $\mathrm{AE7}$ chưa đủ để phân tán tốt các hạt silica vào dung dịch thụ động cũng như để duy trì sự ổn định cho hệ mới chế tạo.

Từ khóa: Cr(III), chất hỗ trợ phân tán, nanosilica, màng thụ động, mạ kẽm. 